\title{
Investigating Species Compositions of Sea Cucumbers in Nam Du Island, Kien Giang Province, Vietnam
}

\author{
Ly Van Khanh*, Nguyen Thi Ngoc Anh and Tran Dac Dinh \\ College of Aquaculture and Fisheries, Can Tho University, Vietnam
}

Submission: March 06, 2020; Published: June 23, 2020

Corresponding author: Ly Van Khanh, College of Aquaculture and Fisheries, Can Tho University, Campus II, $3 / 2$ street, Ninh Kieu district, Can Tho city, Vietnam

Abstract

Six field trips were conducted to assess the species composition and size structure of sea cucumbers at Nam Du Island, Kien Giang province, Vietnam from March to December 2018. Numerous sites covering different depths (1-30 $\mathrm{m}$ ) and habitats (intertidal flats, sea grass beds, rocky beds, and coral reefs) were done during the night by walking and snorkeling diving for collecting sea cucumbers. A total of 389 harvested samples, 14 species were found from two families such as Holothuriidae (8 species) and Stichopodidae (6 species). The most dominant species found around the island was Holothuria leucospilota (32.13\%) followed by Pearsonothuria graeffei (31.11\%) and Stichopus variegatus (17.22\%). Conversely, the high commercial species (H. fuscogilva, H. nobilis and H. scabra) occupied a negligible quantity $(<1 \%)$ that indicated extreme reduction of natural stock of these species. The harvested species were found in the Islands at the depth from 2 to $30 \mathrm{~m}$. The sizes of harvested sea cucumbers in term of length varied from 10 to $47 \mathrm{~cm}$ and their individual weights were between 45 and $1854 \mathrm{~g}$.

Kewords: Sea cucumber composition; Holothuriidea; Stichopodidea; Nam Du Island

\section{Introduction}

Sea cucumbers are among the largest and most diverse classes of benthic marine invertebrate in the intertidal and subtidal zones. They play an important ecological role in benthic communities as deposit feeders [1,2]. Several species of sea cucumbers are edible and during the last two decades, the fishing pressure over this marine resource has been increased due to higher demand for beche-de-mer in the Asian markets leading to severe overexploitation of most commercially important species $[3,4]$. Population declines have generated growing interest in understanding sea cucumber composition. This information could allow the planning of effective fisheries management, taking steps towards conservation and to generate aquaculture initiatives and improvements [5,6]. Southeast Asia is a main source of the global sea cucumber supply. However, a constantly increasing market demand for sea cucumber has led to the overexploitation of traditional fishing grounds and the global expansion of this fishery, which has progressively been including new and less valuable species from both tropical and temperate environments $[1,7,8]$.
In Vietnam, sea cucumbers have been widely exploited for traditional food and medicinal purposes that resulted in a rapid decline of their natural populations and threatens the sustainability of sea cucumber fisheries $[3,9,10]$. Kien Giang province is in the Mekong Delta region of south-western Vietnam. It borders the Gulf of Thailand to the west, Cambodia to the northwest. It shares a $56 \mathrm{~km}$ border with Cambodia, has $200 \mathrm{~km}$ of coastline and $63,290 \mathrm{~km}^{2}$ of fishing grounds, representing one of Vietnam's leading fishing provinces and accounting for nearly $40 \%$ of the Delta's total seafood catch. The sea of Kien Giang contains a total of 143 islands, 105 of which are emerging islands and only 43 of which have residents. Nam Du Island consisting of over 20 islets and rocky outcrops belongs to Kien Giang's coastal waters and is biodiversity hotspots that support many different important marine fisheries, including a high abundance of sea cucumbers. However, several species of sea cucumbers have been commercially harvested in this island, subsequently leading to overexploitation and a decline in the number of sea cucumber species especially high-value commercial stocks $[3,10]$. 
Therefore, investigating sea cucumber species in Nam Du Islands of Kien Giang province could provide the valuable information for planning sustainable sea cucumber management and conservation in the study area.

\section{Survey Methodologies}

\section{Study area}

The Nam Du Island is at the western end of a small chain of islands drifting west of Rach Gia, a thriving port city on the mainland, in Vietnam's western Mekong Delta region. The Nam Du Island locates in the Gulf of Thailand, consisting of over 21 islets, and rocky outcrops. The biggest of these is known as Hon Lon, this island is the center for most of the tourism and infrastructure in the archipelago. Of the outlying islands, several are inhabited, including Hon Ngang, Hon Mau, Hon Trung, Hai Bo Dap, Bai Cay Men... (Figure 1).

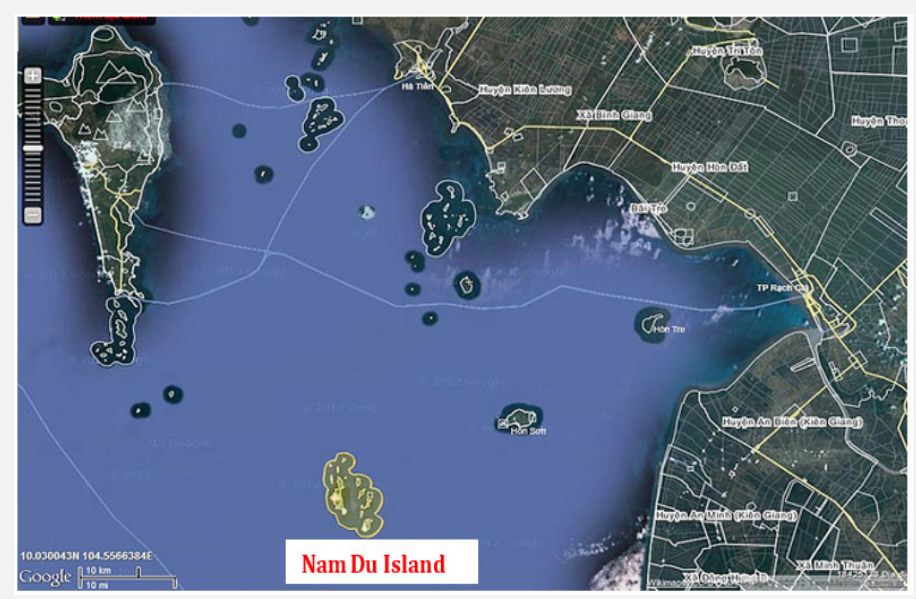

Figure 1: Google map showing the site of sea cucumber sampling in Nam Du islands of Kien Giang province.

The dry season is from November to May, during these months, the skies are generally clear, the sea calm, and the colors luminous. From June to September is the wet season, when prevailing winds from the west bring monsoon rains from the Indian Ocean, the sea can be rough and winds high, boats to the islands are often cancelled at this period.

\section{Sampling time}

Six field trips were conducted (March, April, May, October, November and December, 2018) at various sites in Nam Du Island of Kien Giang province, which covered the intertidal areas, coralline flats, seagrass beds and coral reefs to assess sea cucumber composition. Other time of the year, the sea becomes rough due to high-velocity winds, storms or heavy rainfall; it results in massive waves and turbid water. Therefore, sea cucumber catching could not be done in bad weather conditions. Ecological and natural conditions in the study area were made references to the local investigations.

Sampling time was done at night from 19:00 to 23:00 h, about 50 sea cucumbers or more were randomly collected by local fisherman. Catching sea cucumbers in shallow water (intertidal zones or at low tide at a depth of $\leq 3 \mathrm{~m}$ ) was performed by free diving and either picking them up by hand or using small scoop net. At the depths from $>3 \mathrm{~m}$ to $30 \mathrm{~m}$, fisherman dived with a snorkel apparatus installed an air compressor on their boat to generate oxygen through a pipeline during under water.

\section{Classification Species composition}

The harvested sea cucumbers were identified species composition at the sampling site based on taxonomic study of Ho [11] and Purcell et al. [12]. The species identification was done through morphological keys and review of their ossicles, and each sample was examined, noted and photographed. The total length of animals was measured by ruler and the individual wet weight was determined by electric balance to calculate average values.

\section{Results and Discussion}

\section{Ecological conditions in Nam Du Island}

Environmental conditions in Nam Du Island are based on data from the environmental monitoring project, which was provided by the Department of Agriculture and Rural Development, Kien Giang province (2015-2016). These parameters varied in the ranges as follow: salinity $28-35 \mathrm{ppt}$, temperature: $26-31^{\circ} \mathrm{C}, \mathrm{pH}$ : 8.0-8.6; alkalinity: 80-120 $\mathrm{mg} \mathrm{CaCO}_{3} / \mathrm{L}$; dissolved oxygen: 5.8-7.4 $\mathrm{mg} / \mathrm{L}$, transparency: $60-250 \mathrm{~cm}$. The natural conditions in Nam $\mathrm{Du}$ Island is characterized by existing coral reefs (fringing coral reefs and patch reefs), seaweeds, sea grass beds, rocky beds, etc. and each component supports its own characteristic community structure and zonation. These ecosystems create a large variety of 
flora and fauna of taxonomic and economic importance. Among them are coral reefs and associated with tropical marine fish, sea cucumbers, sea horse, sea urchins, sponges, hemichordates, marine turtles, and ornamental fish (https://vi.wikipedia.org/ wiki/Quan-dao_Nam_Du) [13]. This indicates an appropriate habitat for the development of sea cucumber populations, and other marine organisms in marine areas [14].

\section{Composition of sea cucumber species}

The composition of sea cucumber species collected from March to December 2018 in Nam Du Island was shown in Table 1. Total 389 individuals of sea cucumbers were collected during sampling period, of which 14 species from 2 families (Holothuridea and Stichopodidea) and 4 genera were identified.
Family Holothuriidea had 3 genera with 8 species such as Actinopyga echinites, Pearsonothuria graeffei, Holothuria atra, $H$. fuscogilva, $H$. nobilis, $H$. leucospilota, $H$. impatiens and $H$. scabra where H. leucospilota was most dominant (32.13\%) followed by $P$. graeffei (31.11\%). Other species included H. atra (1.80\%) and $H$. impatiens (1.29\%). While A. echinites, H. fuscogilva, $H$. nobilis and $H$. scabra, each species accounted for less than $1 \%$, which have been categorized high commercial value species. This indicated that the natural stocks of high commercial species have extremely declined in the study area. Similar finding was reported by Hung et al. [15] natural resources of high valuable species ( $H$. fuscogilva and Thelenota ananas) distributing in Khanh Hoa and Binh Thuan marine areas has greatly decreased compared to previous years.

Table 1: Species compositions of sea cucumbers in Nam Du Island.

\begin{tabular}{|c|c|c|c|c|}
\hline Description & Species composition & $\begin{array}{l}\text { Harvested } \\
\text { number }\end{array}$ & $\begin{array}{c}\text { Proportion/total harvested } \\
\text { number }(\%)\end{array}$ & $\begin{array}{l}\text { Commercial } \\
\text { value }\end{array}$ \\
\hline \multicolumn{5}{|c|}{ Family: Holothuriidea } \\
\hline Genus: Actinopyga & $\begin{array}{l}\text { Actinopyga echinites } \\
\quad \text { (Selenka, 1867) }\end{array}$ & 1 & 0.26 & High \\
\hline \multirow{6}{*}{ Genus: Holothuria } & Holothuria atra (Jaeger, 1833) & 7 & 1.8 & Low \\
\hline & Holothuria fuscogilva (Cherbonnier,1980) & 2 & 0.52 & High \\
\hline & $\begin{array}{c}\text { Holothuria impatiens } \\
\text { (Forsskål, 1775) }\end{array}$ & 5 & 1.29 & Low \\
\hline & $\begin{array}{l}\text { Holothuria leucospilota } \\
\text { (Brandt, 1835) }\end{array}$ & 125 & 32.13 & Low \\
\hline & $\begin{array}{c}\text { Holothuria nobilis } \\
\text { (Selenka, 1867) }\end{array}$ & 1 & 0.26 & High \\
\hline & $\begin{array}{l}\text { Holothuria scabra } \\
\text { (Jaeger, 1833) }\end{array}$ & 1 & 0.26 & High \\
\hline $\begin{array}{l}\text { Genus: Pearsono- } \\
\text { thuria }\end{array}$ & Pearsonothuria graeffei (Semper, 1868) & 121 & 31.11 & None valuable \\
\hline \multicolumn{5}{|c|}{ Family: Stichopodidea } \\
\hline \multirow{6}{*}{ Genus: Stichopus } & $\begin{array}{l}\text { Stichopus chloronotus } \\
\text { (Brandt, 1835) }\end{array}$ & 2 & 0.52 & Medium \\
\hline & $\begin{array}{l}\text { Stichopus hermanni } \\
\text { (Semper, 1868) }\end{array}$ & 36 & 9.25 & Medium \\
\hline & $\begin{array}{l}\text { Stichopus horrens } \\
\text { (Selenka, 1868) }\end{array}$ & 10 & 2.57 & High \\
\hline & Stichopus monotuberculatus (Quoy \& Gaimard, 1834) & 9 & 2.31 & Medium \\
\hline & Stichopus naso (Semper, 1868) & 2 & 0.52 & Medium \\
\hline & $\begin{array}{l}\text { Stichopus variegatus } \\
\text { (Semper, 1868) }\end{array}$ & 67 & 17.22 & Medium \\
\hline Total & 14 & 389 & 100 & \\
\hline
\end{tabular}

Another study stated that H. fuscogilva and H. nobilis is one of the most valuable species for 'beche-de-mer' preparation, indiscriminate exploitation and insufficient management measures have caused overexploitation of this species in Kien Giang waters, as evidenced by the decreased natural stock and absence of this species around some of the islands. Many species of sea cucumber in Vietnam have become endangered or threatened with extinction and have been listed in the catalogue of species that must be protected [10]. Family Stichopodidea was found only 1 genus with 6 species, of which $S$. variegatus occupied highest proportion (17.22\%) followed by $S$. hermanni (9.25\%), $S$. horren $(2.57 \%)$, S. monotuberculatus (2.31\%), and 2 other species (S. chloronotus and S. naso) account for $0.52 \%$ in total number of harvested sea cucumbers. 
In the world, genus Stichopus has 13 species i.e. S. chloronotus, S. ellipes, S. hermanni, S. horrens, S. ludwigi, S. monotuberculatus, $S$ naso, S. noctivagus, S. ocellatus, S. pseudohorrens, S. quadrifasciatus, S. rubermaculosus, S. vastus [16]. In Vietnam, genus Stichopus has 6 species namely S. variegatus, S. horrens, S. chloronotus, S. naso [17], S. ocellatus and S. herrmanni were commonly found in Phu Quoc Island [9]. Three field surveys in Vietnamese Island areas were conducted by Dap et al. [18], they found that 18 species belong to 4 families namely Holothuriidae (11 species), Stichopodidae (4 species), Cucumariidae (2 species) and Synaptidae (1 species). A survey from Ngan and nghi [19] found 5 species (S. variegatus, S. herrmanni, S. horrens, S. chloronotus and S. naso) in Nha Trang bay. Other studies reported that genus Stichopus widely distribute across most of the tropical Indo-Pacific region, from the Western Indian Ocean to the Central Pacific, and from southern Japan to northern Australia.

This genus can observe from shallow to deep waters from the intertidal zone to depths of $30 \mathrm{~m}$ on coral reef flats and slopes in dense numbers, of which greenfish sea cucumber $S$. chloronotus is an economically and ecologically important species $[12,20]$. In this survey, vertical distribution of sea cucumbers is different among species e.g. S. horrens and H. leucospilota were found at shallow water at the depths up to $10 \mathrm{~m}$ while $S$. hermanni and $S$. variegatus were found in deeper areas. Overall, genus Stichopus usually found at the depths of more than $20 \mathrm{~m}$, while H. impatiens can be seen at the depth less than $2 \mathrm{~m}$. The current investigation is in line with the early findings $[11,12]$.

Sea cucumber populations have been overexploited all over the world including two families of Holothuridea and Stichopodidae $[1,21]$. Since the processed sea cucumber known as beche-de-mer or trepang, has been a globally important trade commodity, and high demand from Chinese and Southeast Asian markets where they are consumed as food and utilized for traditional medicine [12]. Notably, the occurrence of overfishing due to excessive fishing lead to the discrepancy between the levels of resource utilization of sea cucumbers at a rate of regeneration causing low recruitment of sea cucumber populations in habitats, this would accelerate the extinction of sea cucumber populations $[3,4]$. Additionally, overexploitation results in the risk of extinction of the most commercially valuable species, with 16 species have been classified as "vulnerable" or "endangered" on the IUCN1 red list $[1,21]$. Overexploitation of sea cucumber resources can cause a threat to livelihoods, biodiversity and ecosystem functioning in coastal areas [21].

In Vietnam, several species of sea cucumbers have been intensively harvested in coastal areas and Islands including Kien Giang Sea, consequently leading to overfishing and a reduction in the number of sea cucumber species, especially high-value commercial population $[3,10]$. In the current survey, the quantity of high commercial value species is very low; conversely, the low value species $P$. graeffei and H. leucospilota as well as the medium value species (Stichopus spp.) are commonly found in the study area. These species account for more than $95 \%$ of the total sample collected in the Nam Du Islands. These results are in accordance with the literatures.

\section{Sizes of sea cucumbers}

The sizes of sea cucumbers (expressed as wet weight basis) in Nam Du Islands during survey are summarized in Table 2. Each sampling time, the sizes of harvested sea cucumbers greatly varied among species, even the same species due to random collection in the study area. Sampling from March to May 2019, the mean total weight varied in the ranges of 217.6-1,146.3 g, of which the smallest and largest animals were observed for $H$. leucospilota (101 g) and S. variegatus $(1,854 \mathrm{~g})$, respectively. The average total length ranged from 15.0 to $36.4 \mathrm{~cm}$ with the shortest and longest animals were detected for $S$. hermanni $(12 \mathrm{~cm})$ and $H$. leucospilota $(47 \mathrm{~cm})$, respectively.

Table 2: Sizes of sea cucumbers collected in Nam Du Islands during survey.

\begin{tabular}{|c|c|c|c|}
\hline Species & Harvested number & Total weight (g) & Total length $(\mathrm{cm})$ \\
\hline \multicolumn{4}{|c|}{$3 / 2018$} \\
\hline Actinopyga echinites & 1 & 755 & 28 \\
\hline Holothuria fuscogilva & 2 & $424.5 \pm 331.6(190-659)$ & $26.5 \pm 7.8(21-32)$ \\
\hline Holothuria leucospilota & 21 & $307.6 \pm 94.9(108-452)$ & $29.5 \pm 8.4(18-45)$ \\
\hline Pearsonothuria graeffei & 12 & $490.9 \pm 129.1(207-656)$ & $27.7 \pm 6.7(17-38)$ \\
\hline Stichopus hermanni & 10 & $692.0 \pm 317.9(158-1307)$ & $29.4 \pm 6.1(18-37)$ \\
\hline Stichopus variegatus & 15 & $668.6 \pm 311.9(140-1051)$ & $29.5 \pm 6.8(17-42)$ \\
\hline \multicolumn{4}{|c|}{$4 / 2018$} \\
\hline Holothuria leucospilota & 27 & $217.6 \pm 64.0(101-405)$ & $25.3 \pm 6.7(15-47)$ \\
\hline Pearsonothuria graeffei & 17 & $460.9 \pm 166.6(207-822)$ & $34.5 \pm 6.8(25-45)$ \\
\hline Stichopus hermanni & 4 & $423.3 \pm 257.6(164-721)$ & $15.0 \pm 3.2(12-19)$ \\
\hline Stichopus horrens & 2 & $701.5 \pm 244.0(529-874)$ & $26.0 \pm 2.8(24-28)$ \\
\hline Stichopus variegatus & 5 & $707.0 \pm 210.6(477-1005)$ & $19.2 \pm 2.5(17-23)$ \\
\hline
\end{tabular}




\section{Oceanography \& Fisheries Open access Journal}

\begin{tabular}{|c|c|c|c|}
\hline \multicolumn{4}{|c|}{$5 / 2018$} \\
\hline Holothuria leucospilota & 16 & $431.5 \pm 134.5(211-632)$ & $36.4 \pm 5.1(27-44)$ \\
\hline Holothuria scabra & 1 & 397 & 24 \\
\hline Pearsonothuria graeffei & 29 & $461.7 \pm 121.6(118-813)$ & $27.3 \pm 5.0(18-40)$ \\
\hline Stichopus chloronotus & 1 & 547 & 23 \\
\hline Stichopus horrens & 3 & $1146.3 \pm 566.0(595-1,726)$ & $26.7 \pm 1.2(26-28)$ \\
\hline Stichopus variegatus & 12 & $1,053.9 \pm 465.5(392-1,854)$ & $29.1 \pm 6.0(21-40)$ \\
\hline \multicolumn{4}{|c|}{$10 / 2018$} \\
\hline Holothuria impatiens & 3 & $103.0 \pm 54.8(45-154)$ & $18.3 \pm 3.1(15-21)$ \\
\hline Holothuria leucospilota & 20 & $263.3 \pm 125.8(64-544)$ & $26.8 \pm 8.1(16-43)$ \\
\hline Pearsonothuria graeffei & 15 & $256.5 \pm 150.2(42-480)$ & $23.1 \pm 5.3(14-31)$ \\
\hline Stichopus hermanni & 5 & $431.6 \pm 182.3(137-615)$ & $24.6 \pm 3.9(18-28)$ \\
\hline Stichopus horrens & 3 & $308.0 \pm 194.4(107-495)$ & $20.7 \pm 4.2(16-24)$ \\
\hline Stichopus monotuberculatus & 9 & $198.1 \pm 107.0(64-355)$ & $18.5 \pm 4.5(12-24)$ \\
\hline Stichopus naso & 2 & $134.0 \pm 90.5(70-198)$ & $12.5 \pm 3.5(10-15)$ \\
\hline Stichopus variegatus & 18 & $373.1 \pm 164.0(82-590)$ & $21.4 \pm 4.7(12-28)$ \\
\hline \multicolumn{4}{|c|}{$11 / 2018$} \\
\hline Holothuria atra & 2 & $169.5 \pm 65.8(123-216)$ & $19.0 \pm 1.4(18-20)$ \\
\hline Holothuria nobilis & 1 & 207 & 19 \\
\hline Holothuria impatiens & 2 & $141.5 \pm 79.9(85-198)$ & $21.5 \pm 6.4(17-26)$ \\
\hline Holothuria leucospilota & 22 & $317.1 \pm 165.9(56-590)$ & $25.2 \pm 7.4(13-41)$ \\
\hline Pearsonothuria graeffei & 25 & $447.1 \pm 190.7(101-768)$ & $29.4 \pm 53(19-38)$ \\
\hline Stichopus hermanni & 7 & $239.6 \pm 147.2(83-421)$ & $21.1 \pm 4.2(16-27)$ \\
\hline Stichopus variegatus & 8 & $211.8 \pm 131.1(69-420)$ & $22.1 \pm 4.4(15-29)$ \\
\hline \multicolumn{4}{|c|}{$12 / 2018$} \\
\hline Holothuria atra & 5 & $641.8 \pm 282.1(215-920)$ & $33.6 \pm 4.7(27-40)$ \\
\hline Holothuria leucospilota & 19 & $635.9 \pm 291.3(128-1,067)$ & $31.3 \pm 7.3(22-44)$ \\
\hline Pearsonothuria graeffei & 23 & $668.2 \pm 377.9(85-1329)$ & $29.6 \pm 8.6(14-42)$ \\
\hline Stichopus chloronotus & 1 & 783 & 27 \\
\hline Stichopus hermanni & 10 & $788.5 \pm 344.3(224-1,297)$ & $29.5 \pm 5.9(22-38)$ \\
\hline Stichopus horrens & 2 & $264.5 \pm 77.1(210-319)$ & $23.5 \pm 2.1(22-25)$ \\
\hline Stichopus variegatus & 9 & $703.7 \pm 189.6(279-887)$ & $31.9 \pm 4.9(23-41)$ \\
\hline
\end{tabular}

Mean \pm SD; data in the parentheses indicate min and max values

Sampling from October to December 2019, the total weight of sea cucumbers averaged from $103.0 \mathrm{~g}$ to $788.5 \mathrm{~g}$, of which $H$. impatiens had smallest size ( $45 \mathrm{~g}$ ) and $S$. hermanni had largest individual weight $(1,297 \mathrm{~g})$. The total length fluctuated in the mean range of $12.5-33.6 \mathrm{~cm}$ with the lowest value $(10 \mathrm{~cm})$ was found for $S$. naso and highest value $(44 \mathrm{~cm})$ was observed for $H$. leucospilota. Other findings reported that most of species belong to genus Stichopus are quite large size but their lengths are relatively short, this is because of their body structure is cylindrical, not too long, the width and height of the body is quite large, the body wall is quite thick resulting in relatively heavyweight $[12,19]$. On the contrary, the body structure of $H$. leucospilota is characterized by narrow width and thin body wall resulting in cylindrical and elongate body shape [12].

It was noted that the randomly harvested sea cucumbers between March and May obtained bigger animals than those collected from October to December in the current survey. This could be related to spawning seasons of sea cucumbers. According to Chao et al. [22], tropical sea cucumbers (Holothuroidea) have annual spawning periods lasting 2 to 4 months in spring or summer. In another study reported that spawning seasons 
of sea cucumber happens mostly from June to August and is accomplished by shedding sperm and eggs into the water where fertilization takes place [23]. Therefore, random catching of sea cucumber between October and December usually obtains young animals with small sizes (Figure 2).
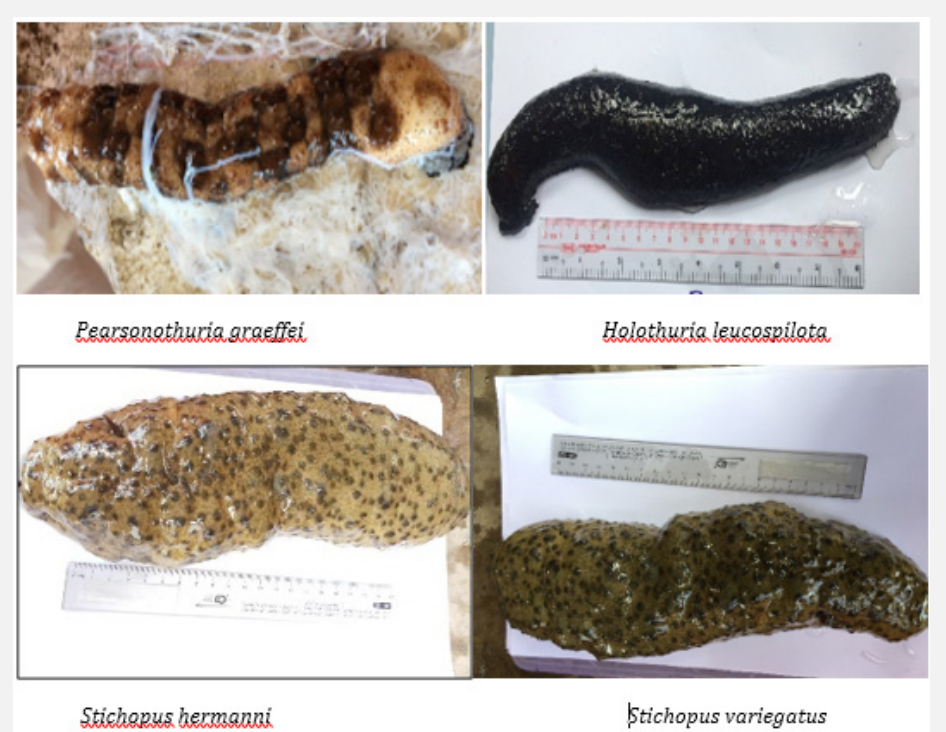

Figure 2: Photos of sea cucumber species commonly found in Nam Du Island, Kien Giang province.

\section{Conclusion}

The recorded population of sea cucumbers at Nam Du Island, Kien Giang province, Vietnam present 14 species from family Holothuriidae (8 species) and Stichopodidae (6 species). Notably, most high commercial species (Actinopyga echinites, Holothuria fuscogilva, H. nobilis, H. scabra) were rarely found in the study area. This indicated these species have faced numerous threats from overexploitation, which could lead to severe depletion of natural stocks and imbalance of ecosystem. Therefore, immediate action for protecting the habitat in conserving sea cucumber species as well as the status, biology, reproduction and ecology of the sea cucumbers especially those with high commercial value must also be done in this Island.

\section{Acknowledgment}

This study belongs to the ODA F-3 project "Fisheries resource management and conservations", which is funded by the Can Tho University Improvement Project VN14-p6, supported by a Japanese ODA loan. The authors are grateful to a local fisherman Phan Van Doi who collected sea cucumbers during survey period. A special thanks to Le Thanh Tu, Tran Thi Diem Hang and Truong Hoang Son for their helps with identification of sea cucumbers.

\section{References}

1. Anderson S C, J M Flemming, R Watson, H K Lotze (2011) Serial exploitation of global sea cucumber fisheries. Fish and Fisheries 12(3): 317-339.
2. Slater M J, J Chen (2015) Sea Cucumber Biology and Ecology. In: N Brown \& S Eddy (Eds), Echinoderm Aquaculture, P. 47-57.

3. Choo P S (2008) Population status, fisheries and trade of sea cucumbers in Asia. In: Toral-Granda V, Lovatelli A and Vasconcellos M (eds). Sea cucumbers. A global review of fisheries and trade. FAO Fisheries and Aquaculture Technical Paper No. 516. Rome, P. 81-118.

4. Eriksson H, M De la Torre-Castro, P Olsson (2012) Mobility, expansion, and management of a multi-species scuba diving fishery in East Africa. PLoS ONE 7(4): e35504.

5. Purcell S W (2014) Value, market preferences and trade of Beche-demer from Pacific Island sea cucumbers. PLoS ONE 9(4): e95075.

6. Devanadera M, K R U Velasco, M L Lopez (2015) Diversity, exploitation and conservation status of commercially important sea cucumber (class Holothuroidea) species in Southeast Asia. Philippine Journal of Systematic Biology IX: 34-45.

7. Rahman M A, F M Yusoff, A Arshad (2015) Sea cucumber fisheries: global status, culture, management and extinction risks. IJCEBS 3(4): 344-348.

8. Rahman M A, F M Yusoff (2017) Sea cucumber fisheries: Market potential, trade, utilization and challenges for expanding the production in the South-East Asia. IJACEBS 4(1): 26-30.

9. Otero-Villanueva M, V N Ut (2007) Sea cucumber fisheries around Phu Quoc Archipelago: a cross-border issue between South Viet Nam and Cambodia. SPC Beche-de-mer Information Bulletin 25: 32-36.

10. Tuan V S (2013) Conservation and reasonable use of biodiversity resources in Phu Quoc Islands (Vietnam). In: Conservation and promotion of the values of the Kien Giang Biosphere Reserve-Vietnam. Workshop Proceedings, Agriculture Publishing House Ho Chi Minh City 118-136. 
11. Ho D T (1991) Sea Cucumbers (Holothuroidea) in the South of Vietnam. Proceedings of Scientific Research, National Scientific Research Conference on the Sea (III). Vietnam-Hanoi Science Institute.

12. Purcell S W, Y Samyn, C Conand (2012) Commercially important sea cucumbers of the world. FAO Species Catalogue for Fishery Purposes, Rome, 6: 150

13. https://vi.wikipedia.org/wiki/Quan-dao_Nam_Du

14. Dissanayake D C T, G Stefansso (2010) Abundance and distribution of commercial sea cucumber species in the coastal waters of Sri Lanka. Aquatic Living Resources 23(03): 303-313.

15. Hung N V, T N M Nga, D N Hao (2017) A survey of resources of white teatfish (Holothuria fuscogilva Cherbonnier, 1980) and prickly red fish (Thelenota ananas Jaeger, 1833). Journal Fisheries Science \& Tech 3 28-35.

16. Paulay G (2015) Stichopus Brandt, 1835. Accessed through: World register of marine species at http://www.marine species.org/aphia. php?p=taxdetails\&id=123459.

17. Hoeksema B W, A Gittenberger (2008) Records of some marine parasitic molluscs from Nha Trang, Vietnam. Basteria 72: 129-133.
18. Dap V D, N V Giang, P T Anh (2012) Survey status of species composotion and distribution of cucumber in some offshores of Vietnam. Journal Fisheries Science \& Tech 1: 56-70.

19. Ngan N T M, B Q Nghi (2015) Description of Stichopus sp. (Phylum Echinodermata-Class Holothuroidea) collected in Nha Trang bay. Collection of Marine Research Works 21(2): 136-141.

20. Soliman T, O Takama, I Fernandez-Silva, J D Reimer (2016) Extremely low genetic variability within and among locations of the greenfish holothurian Stichopus chloronotus Brandt, 1835 in Okinawa, Japan. Peer J 4: e2410.

21. Robinson G, A Lovatelli (2015) Global sea cucumber fisheries and aquaculture FAO's inputs over the past few years. FAO Aquaculture Newsletter 53: 55-57.

22. Chao S M, C P Chen, P S Alexxander (1995) Reproductive cycles of tropical sea cucumbers (Echinodermata: Holothuroidea) in southern Taiwan. Marine Biology 122: 289-295.

23. Smiley S, F S McEuen, C Chaffee, S Krishnan (1991) Echinodermata: Holothuroidea. In: Giese AC, Pearse JS, Pearse VB (eds) Reproduction of marine invertebrates, Echinoderms and Lophophorates. Boxwood, Pacific Grove, California, USA, Pp. 663-750.

\section{Your next submission with Juniper Publishers will reach you the below assets}

- Quality Editorial service

- Swift Peer Review

- Reprints availability

- E-prints Service

- Manuscript Podcast for convenient understanding

- Global attainment for your research

- Manuscript accessibility in different formats

( Pdf, E-pub, Full Text, Audio)

- Unceasing customer service

Track the below URL for one-step submission https://juniperpublishers.com/online-submission.php 